\title{
Special Education Teachers' Perception Towards the Use of Information and Communication Technology (ICT) in Classroom
}

\author{
Rajasree Karunamoorthy $^{1 *}$, Farah binti Mukhtar ${ }^{1}$, Ranjanie Karunamoorthy ${ }^{2}$, \\ Viknesvaran Sukumaran ${ }^{3}$
}

\author{
${ }^{1} I P G$ Kampus Raja Melewar, Negeri Sembilan, Malaysia \\ ${ }^{2} S J K(T)$ Jalan Haji Manan, Kluang, Johor, Malaysia \\ ${ }^{3}$ SK Air Kuning Selatan, Gemencheh, Negeri Sembila, Malaysia \\ *Corresponding author. Email: rajasreekarunamoorthy@gmail.com
}

\begin{abstract}
The use of ICT among students with special needs is influenced by the perception of special education teachers towards ICT. This study was conducted to identify the perceptions of Special Education teachers on the use of Information and Communication Technology in the classroom. This is a survey study using quantitative approach. A total of 95 primary school teachers in Negeri Sembilan were randomly selected to be the sample. The collected data were analyzed using SPSS version 20 software. The findings of this study indicate that the level of perception of the Special Education teachers towards the use of ICT is high but the level of use of the ICT by the Special Education teachers is moderate. This result of the study also shows that special education teachers are aware of the use of ICT in improving problem solving skills. The results indicate that local special education teachers agreed that the use of ICT exposes special needs students to new knowledge that enhance their thinking skills and can allow them to apply the knowledge in daily life. Furthermore, this study also shows that there is a significant relationship between teachers' perceptions and the use of ICT in the classroom. This significant relationship indicates that teachers' perceptions influence the practice of using ICT in the classroom.
\end{abstract}

Keywords: Information and communication technology (ICT), teacher perceptions, special education

\section{INTRODUCTION}

In this era of globalization, Information and Communication Technology (ICT) has made a huge impact in all areas including education. The impact of the use of ICT in education has been studied since the early 1970s and most researchers have begun to believe that the use of ICT can support students in formal education (Stevens, 2004). In Malaysia, the Ministry of Education has given serious attention to the use of Information and Communication Technology in the classroom. This is especially evident when the MOE spends over RM 6 billion to compensate the ICT infrastructure in schools across the country (Kumaran, 2017) as well as organizing various trainings for teachers at the schools, district and state levels. In addition, the Malaysian Education Development Plan Report 2013-2025 outlined the use of ICT in the classroom is one of the most important issues (Kamis, N., \& Khalid, F., 2017).
Although the use of ICT in the classroom is highly emphasized in schools, its use has not reached satisfactory levels, either in terms of quality or quantity in line with the opinions of Kamis, N., \& Khalid, F. (2017). The use of ICT in teaching and learning is just emphasized in mainstream students. In fact, special needs students also have the right to receive the equal and quality-based education as the mainstream students. According to the Malaysian Federal Government Gazette (2013), Special Education is a form of education given specially to special needs students at all levels of school who cannot attend mainstream education. This is because students with special needs have various types of learning disabilities ranging from physical disabilities, behaviours, and so on (Florian, L., \& Hegarty, J., 2004) which require them to be taught different teaching and learning techniques and strategies compared to typical students (Sheila \& Samsilah, 2006). 
ICT plays an important role in education for special needs students in order to provide them with quality education. ICT in special education was introduced to ensure the smooth running of the teaching and learning process, to meet the needs of students with various abilities and to gain the active involvement of students. The use of ICT in the teaching and learning of special needs students has a positive impact on the development of language, physical, behavioural, social, emotional and other domains. The use of ICT in special education is specific to each student. Use of ICT in the classroom takes into account the type of ICT in terms of student needs. ICT for students with special needs focuses more on applications.

In recent times, there have been many researchers who have argued that ICT and assistive technology enable students with special needs to live better (Steven, 2004, William et al., 2006). Good integration of ICT into the learning environment can have a positive effect on special needs students as mainstream students. Therefore, special education teachers should equip themselves with a variety of effective teaching techniques and strategies so that students with special needs could benefit. Hutchison, A. \& Reinking, D. (2011) study has shown that the use of ICT in special needs student learning is very effective in enhancing understanding due to the combination of various learning styles such as auditory, visual and so on. This is because the individual differences in pupils make the learning styles different. The use of ICT incorporates a variety of learning styles to enhance student understanding.

The use of multimedia and visual elements in learning can make students to be more attracted, interested and engaged in learning by exploring and following the learning process (Jamalludin \& Siti Nurulwahida, 2010, Shaharuddin \& Ahmad Khairi 2011). In addition, multimedia and visual elements make poor students improve their memory of processed information. The combination of text, graphics, audio and so on can influence students 'motivation in the process of receiving information and bring a realistic element or situation to the user by influencing their users' feelings and emotions (Jamalludin \& Zaidatun, 2003). The use of ICT in education facilitates educators to run the teaching and learning more smoothly and effectively (Andin and Hazman, 2010) and to enhance student engagement (Kamis, N., \& Khalid, F., 2017).

Over the decades, there have been numerous studies that discuss how ICT in teaching and learning affects the learning of special needs children. Gregor, P. et al., (2003) have developed Seeword software for dyslexic children to help them read texts. He found that children with dyslexia can read text accurately with the help of the Seeword application instead of looking at text in a book. In addition, Van der Molen, M. et al., (2010), studied the effectiveness of the Odd Yellow application in improving students' memory impairment. He found that there was an increase in memory recognition after the intervention using this ICT application. A computer game called The Number Race was developed by Wilson, A. J., et al., (2006) proving that the game enhances the numeracy skills of students who often have problems in math.

Although the findings of previous studies show that ICT can help students with special needs in many aspects, teachers' perception of ICT strongly influences the use of ICT in the classroom. Teachers' perceptions of ICT relate closely to the integration of ICT in teaching and learning activities as well as the challenges teachers face when using ICT in education (Hutchison, A. \& Reinking, D., 2011). Wang (2012) argues that teachers' perceptions of the use of ICT may explain how a teacher perceives, understands and interpret the use of ICT in learning. In short, teachers' perceptions are crucial in determining the success or failure of the ICT integration in education (Apeanti, W. 2014). Therefore, teachers' perceptions, acceptance and attitude towards the use of ICT need to be studied in order to understand the practices of integrating ICT in the classroom (Hutchison, A. \& Reinking, D., 2011).

\section{PROBLEM STATEMENT}

Education for special needs students is a very important and concerning issue for the Ministry of Education Malaysia. Special education teachers play an important role in the education of special needs students. Special education teachers need to equip themselves with ways of managing and controlling special needs children from mild to profound categories (Emery \& Vandenberg, 2010). However, several studies have shown that special education teachers face problems in managing and controlling children (Prather Jones, 2011).

The lack of variety of teaching methods during teacher's teaching cause students to get bored easily. This is in line with Plump \& Larosa (2017) which states that the inconsistent teaching and learning process causes students with special needs to become bored and exhibit disruptive behavior in the classroom. To prevent this scenario from happening, Van der Molen, M. et al., (2010) call on Special Education teachers to use a variety of teaching methods that can engage students in reducing learning, behavior, social and emotions dimensions. The integration of ICT into teaching and learning can enhance student interest and help students understand the content easily. 
Although teachers generally admit that they have an interest and are willing to use computers in teaching and learning, the fact is that their attitude is negative because most teachers are less skilled at managing the ICT (Hamzah \& Attan, 2010). Nor'Aini Ahmad's (2010) study also showed similar findings where most teachers are not proficient in computer-related learning.

Indeed, the use of ICT can enhance special needs students' understanding and make teaching and learning more effective, but ICT is still less emphasized in the field of special education. Studies on teachers' perceptions of ICT use in the classroom have been conducted extensively. However, studies on the perceptions of special education teachers on the use of ICT in their classroom in primary schools are still vaguely investigated and emphasized. Therefore, to add new knowledge in the field of research, a study was conducted by researchers to determine the perception of Special Education teachers on the use of ICT in the classroom in primary schools. The objectives of this study are as follow:

1. Identify perceptions of teachers in Integrated Special Education Programme on the use of ICT in the classroom.

2. Identify the level of use of ICT by Integrated Special Education Programme teachers in the classroom.

3. Identify the significant relationship between Integrated Special Education Programme teachers' perceptions on using ICT in the classroom.

\section{METHOD}

This is a quantitative study using survey design. The survey design of this study was chosen because of its importance in gaining public opinion on a current issue (Creswell, 2012). In this study, the researcher chose cross sectional type survey as it appropriately measures the level of perception of Special Education teachers towards the use of ICT. Lay \& Khoo (2012), stated that crosssectional survey studies were used to obtain an overview of educational opinions and practices at a particular time. Therefore, the selection of cross sectional survey studies is appropriate because the sample of the study was selected from a predetermined population and all study data was collected at a particular time.

The sample of this study was selected based on a simple random sampling method. Researchers distributed 105 questionnaires to special education teachers in Seremban city and 95 questionnaires were received. The questionnaire used was adapted from the Malakia. J \& Cloneria

N. J, (2018), study according to local elements and teaching context of Special Education teachers. This questionnaire has 17 closed-ended questions. The questionnaire in this study used a 5-Likert scale to represent respondents' answers to the questions posed apart from to capture the respondents' actual perceptions.

The researchers conducted a pilot survey of 30 Special Education teachers in Negeri Sembilan. The Cronbach's Alpha value obtained from the pilot study was 0.832 . According to Patten, M. L., \& Newhart, M. (2017), Cronbach's Alpha values between 0.8 and 0.9 indicate that this questionnaire has high reliability. Data collected were analyzed using the SPSS version 20 program with descriptive analysis (frequency and mean) and inference analysis (Pearson correlation).

\section{DISCUSSION AND FINDINGS}

The study was conducted to (i) identify the perceptions of special education teachers on the use of ICT in the classroom, (ii) identify the level of use of ICT by special education teachers and (iii) identify the significant relationship between teachers' perceptions and use of ICT. Therefore, the data collected are analyzed based on the three research questions that have been developed. The sample of this study consisted of 95 teachers of Integrated Special Education Program serving primary schools around Seremban town. The perceptions of special education teachers and the level of use of ICT were analyzed descriptively by looking for mean values and averaged with the mean interpretation table. Table 1 is the profile of the respondents based on their experience of using ICT.

experience.

Table 1. Respondents profile according to their ICT usage

\begin{tabular}{lccccccc}
\hline Gender & \multicolumn{7}{c}{ Experience in using ICT } \\
\cline { 2 - 8 } Male & Age & Never & $1-5$ years & $6-10$ years & $11-15$ years & $16-30$ & Total \\
& & & & & & years & 3 \\
& 20-29 years & 0 & 2 & 1 & 0 & 0 & 0 \\
& $30-39$ years & 0 & 2 & 7 & 3 & 0 & 3 \\
& $40-49$ years & 0 & 0 & 1 & 2 & 1 & 2 \\
& $50-59$ years & 1 & 0 & 0 & 0 & 1 & 20 \\
\hline Female & Total & 1 & 4 & 9 & 5 & 0 & 4 \\
\hline
\end{tabular}




\begin{tabular}{ccccccc}
\hline $30-39$ years & 1 & 11 & 27 & 4 & 1 & 44 \\
$40-49$ years & 0 & 2 & 10 & 6 & 1 & 19 \\
$50-59$ years & 1 & 1 & 1 & 4 & 2 & 8 \\
Total & 1 & 17 & 39 & 14 & 4 & 75 \\
\hline
\end{tabular}

According to Table 1, the use period of 6-10 years has a high frequency of male teachers of 9 . A total of 5 male teachers used ICT for 11-15 years while 4 male teachers used ICT for 1-5 years. However, there is a male teacher who has never used ICT in teaching and learning. For female teachers, 39 teachers use ICT for $6-10$ years but 17 teachers use ICT for only 1-5 years. There were also 14 female teachers who used ICT for 11-15 years and 4 teachers for 16-30 years. Based on this table, it is found that a female teacher has never used ICT in teaching and learning. In terms of age there are 4 age categories namely 20-29 years, 30-39 years, $40-49$ years and 50-59 years. The age group of 30-39 years has the highest frequency and the majority

of 34 teachers use ICT for 6-10 years. 13 teachers used ICT for 1-5 years, 7 teachers for 11-15 years and another used ICT for 16-30 years. 11 teachers from the 40-49 age group, using ICT for 6-10 years, 8 from 11-15 years old, 2 others from 1-5 years and one from 16-30 years old. On the other hand, ages 20-29 have relatively small respondents of only 7 teachers. In the age group of 20-29 years, 5 teachers use ICT for 1-5 years while 2 teachers use it for 6-10 years.

What is the perception of teachers of the Integrated Special Education Program on the use of ICT in the classroom?

The use of ICT in teaching and learning has a positive impact on special needs students' education. This impact is evident in Gooch, D., Vasalou, A., Benton, L., \& Khaled, R. (2016) study where the use of gamification (ICT) can increase student motivation and help students understand the content easily. Although ICT has a positive impact on the development of special needs students', its level of use in the classroom is still questionable. The findings of the study show that the Special Education teachers have a high level of perception of the use of ICT in teaching and learning for special needs students' which is 3.98 . The high level of understanding explains that Special Education teachers have a positive view of the use of ICT and would like to use it in the teaching and learning. The theory of Technology Acceptance Model (TAM) used in this study suggests that one needs to believe that the use of ICT can improve one's performance and that ICT can be used easily (Apeanti, 2014). The high mean indicate that Special Education teachers in Seremban district believe that ICT can improve special needs students' performance and that it is easy to use in the classroom.

Table 2. Teachers' perceptions of the use of ICT in the classroom

\begin{tabular}{llcc}
\hline Item & SD & Mean & Level \\
\hline 1. The use of ICT makes teaching easy. & 0.58 & 4.38 & high \\
2. The use of ICT promotes students' thinking skills. & 0.65 & 4.17 & high \\
3. The use of ICT promotes innovation skills among the pupils & 0.79 & 3.95 & high \\
4. The use of ICT promotes problem solving skills among my students. & 0.79 & 3.90 & high \\
5. The use of ICT encourages my students to explore new information. & 0.79 & 3.97 & high \\
6. The use of ICT helps improve the quality of education. & 0.62 & 4.31 & high \\
7. Teachers should be encouraged to use ICT in teaching and learning & 0.60 & 4.25 & high \\
8. I find the use of ICT in teaching and learning take a long time. & 1.21 & 2.97 & low \\
9. Lack of ICT skills causes teachers to fail current developments in education. & 0.89 & 3.85 & high \\
Overall mean & $\mathbf{0 . 5 1}$ & $\mathbf{3 . 9 8}$ & high \\
\hline
\end{tabular}

Teacher approval of ICT can improve special needs students' performance and is easy to see with high means (above 3.67) on certain items. Among them are Special Education teachers who agree that the use of ICT facilitates teaching with a mean of 4.38 . Teacher approval indicates that teachers' acceptance of ICT in their teaching is expected to improve the quality of life of the special needs students. The findings of this study can be corroborated by Chiappe's (2016) study which states that the use of ICT facilitates teacher teaching by referencing various sources for lesson planning. With the use of ICT, teachers can find ideas in designing teaching and learning activities, worksheets, and videos based on the content of teaching topics.

In addition, the use of ICT promotes thinking skills among students. Our neighboring Thailand emphasizes the use of ICT in teaching and learning so that students can improve their thinking skills through online resources 
(Office of the National Education Commission, 2003). The mean of this question is 3.95 which indicate that local special education teachers have similar views. This indicates that the use of ICT exposes special needs students to new knowledge that enhance their thinking skills and can allow them to apply the knowledge in daily life.

Furthermore, the use of ICT can foster innovation skills among students with special needs. Special education teachers in Seremban agree with this statement with a mean of 3.95. According to Ghavifekr \& Rosdy (2015), innovation is a refinement and adaptation to the thinking, an existing idea that gives rise to new values that can be applied and utilized. Through this definition, we can see that innovation is an idea of improvement from existing products. The use of ICT in the classroom exposes students to new knowledge. The introduction of these new ideas encourages students to make improvements in order to bring about new innovations. These innovation skills can be applied to students with special needs through the use of ICT.

The findings of this study also show that special education teachers are aware of the use of ICT in improving problem solving skills and even agree with this statement with a mean value of 3.90. This is supported by the findings of the Amethyst Consultancy (2003) study that indicated the Roamer Robot application is successful in developing problem solving skills in children through interaction with robots. The findings of Fessakis, G., Gouli, E., \& Mavroudi, E., (2011), also found that the use of interactive white boards improves children's ability in problem solving skills. In short, the use of ICT can improve problem solving skills in children as well as students with special needs.

The results of this study are in line with the with Ari and Inan's (2010) study, where the use of ICT for What is the Level of Use of ICT by Special Education teachers?

Table 3. Levels of ICT use by Special Education teachers teaching and learning for special needs students can help them to explore new knowledge. The Internet has a plethora of information and makes it easy for students to explore new knowledge based on their abilities and interests. The use of ICT in teaching and learning for students with special needs can help them learn new knowledge with a combination of visual, auditory and kinesthetic elements. This is because ICT includes videos, pictures and applications that help students to learn and understand new knowledge.

Special Education teachers agree that ICT can improve the quality of education by indicating a mean of 4.31. This is because it is in line with today's educational trends that emphasize ICT as the main source of teaching. The findings of this study are further reinforced by the findings of Ghavifekr and Rosdy (2015), where teachers believe that the use of ICT can improve the quality of the education system and encourage teachers to engage in professional training related to ICT. This finding clearly shows that the use of ICT in the classroom can promote quality learning among students as well as for students with special needs. The findings of this study also affect the statement that teachers should be encouraged to use ICT in the classroom. This is because ICT helps teachers to provide quality teaching and learning in the classroom.

The teacher's perception of the use of ICT is influenced by the teacher's motivation for using the ICT. This is evidenced by the study of Hassanzadeh (2012), who found that motivation acts as a key pillar in fostering teachers' positive attitude towards ICT. Therefore, teachers' motivation needs to be enhanced in order to foster a positive attitude towards the use of ICT in the classroom.

\begin{tabular}{|c|c|c|c|}
\hline Item & SD & Mean & Level \\
\hline $\begin{array}{l}\text { 1. I always use ICT equipment (Computers / laptops with internet) to find information on planning and } \\
\text { preparation of the Lesson Plan. }\end{array}$ & 0.71 & 4.34 & high \\
\hline $\begin{array}{l}\text { 2. I use ICT (interactive boards / projectors) to enhance student interaction and interest within teaching } \\
\text { and learning. }\end{array}$ & 0.89 & 3.89 & high \\
\hline 3. I only use ICT when needed in teaching and learning. & 0.87 & 3.73 & high \\
\hline 4. I use a computer with internet in the classroom. & 1.08 & 3.82 & high \\
\hline 5. I allow my students to use electronic equipment during teaching and learning. & 1.01 & 3.47 & moderate \\
\hline 6. I prefer to use ICT alone when no one is around to see me make a mistake. & 1.31 & 3.30 & moderate \\
\hline 7. I use different ICT tools confidently during teaching and learning. & 0.92 & 3.78 & high \\
\hline 8. I only have access to the computer in the computer lab. & 1.25 & 2.47 & moderate \\
\hline Overall mean & 0.46 & 3.61 & moderate \\
\hline
\end{tabular}

\section{Levels of ICT use by Special Education teachers}


The results of this study found that the use of ICT among special education teachers in Seremban city was at a moderate level where the mean value obtained from all related items was 3.61 (below 3.67). Special Education Teachers use ICT (computer / laptop / internet) equipment for the purpose of finding information in the planning of the Lesson Plan. This statement had the highest mean of 4.34. This indicates that teachers are actively using the ICT equipment to obtain new information and ideas in planning their classroom activities. In addition, special education teachers use ICT to enhance the interaction and interest of students with special needs in the teaching and learning. According to Cox and Preston (2000), teaching using ICT is fun for students and increases students' motivation to continue learning. The teachers in this study agreed that the use of ICT was enjoyable by ICT with a mean of 3.89 . This is because the exciting combination of visual, audio and animation enhances student interest and student enjoyment.

Special Education Teachers agree that they use different ICT applications confidently during teaching and learning with a mean of 3.78. Teacher's agreement to this statement indicates that Special Education teachers have confidence in the use of ICT. The findings of the study show that the level of teachers' modest agreement with the statement is that they are using the ICT alone so that no one is around to see the error. This shows that Special Education teachers have a moderate confidence in the use of ICT.

Many researchers find that low self-esteem to be one of the main factors that prevent teachers from using ICT in the classroom (Bingimlas, 2009). Teachers who have good ICT skills do not necessarily have high confidence in using ICT in the classroom. According to Pede (2017), most teachers are afraid of using ICT in the classroom because they have students who are proficient in the ICT including special needs students. This finding indicates that teachers have low confidence in using ICT in the classroom. Most of the respondents in this study were young teachers in the 30-39 age group who have a firm grasp of ICT literacy. Therefore, the confidence of the teachers is higher than the confidence of the teachers who influence the findings of this study.

In addition, the findings show that teachers are less inclined to allow students to use electronic media such as iPads, tablets, and computers during teaching and learning. This is because special education teachers think that the use of electronic media makes special education pupils more focused on gadgets than teacher teaching. The findings of the Sánchez-Mena and Martí-Parreño (2017) study suggest that some teachers consider the use of a gamification approach in the classroom to be disruptive to teachers and students who are nearby because one of the special needs of students is that they are easily distracted by noisy environment. Therefore, they do not encourage students to use these gadgets during teaching and learning.

The mean of items I only have access to computers in the computer lab indicating that Special Education teachers have access to computers wherever they are. However, there are still teachers who rely on prepared computer help in computer labs because they do not have their own computers. Not to mention, Special Education teachers use ICT as needed in teaching and learning. It shows that the use of ICT is influenced by its suitability in a particular topic of learning to teach. For example, if a teaching topic involves a process, the teacher presents a video related to the process. Thus, we can conclude that special education teachers use ICT as needed according to their relevance to the topic of learning.

Overall, the level of use of ICT by Special Education teachers was moderate. The findings of this study may be influenced by the workload of teachers. Many studies have shown that special education teachers experience greater stress than mainstream teachers (Sim \& Norasmah Othaman, 2017). In addition to teaching, special education teachers take the time to carry out other tasks as they face time constraints to plan and implement new approaches such as the use of ICT in the classroom. Special education teachers are often burdened with other tasks such as cocurricular activities, school activities, and clerical tasks (Prather-Jones 2011). As such, it has been proven that the additional tasks of Special Education teachers are limiting the use of ICT in the classroom. The problem of teacher load needs to be addressed in order to encourage teachers to use ICT in teaching and learning who need to improve their quality of life.

\section{Is there a significant relationship between perceptions of special education teachers and the level of use of ICT?}

Table 4. Relationships between teacher perceptions and use of ICT

\begin{tabular}{llll}
\hline Teacher perception & & \\
\hline ICT usage & $\begin{array}{l}\text { Correlation } \\
\text { significance } \\
\text { decimal })\end{array}$ & $(2$ & $0.542^{* *}$ \\
& & \\
\hline
\end{tabular}

*significance at 0.01 (2 tailed)

Based on the table, it is found that teachers' perception and use of ICT indicate a correlation coefficient of 0.542. According to Hair, Celsi, Mowey, Samuel and Page (2016), if the correlation coefficient ranges from 0.41 to 
0.70 , then the relationship is at a moderate level. The correlation coefficient in the table, which is 0.542 is moderate. The $\mathrm{p}$ values in the table are $0.000,0.000 \leq$ 0.001 indicating a significant relationship between perception and use of ICT. This finding indicates that there is a significant relationship between teachers' perceptions and the use of ICT in the moderate level. Thus, this finding suggests Ho hypothesis that there is no significant relationship between perception and use of ICT among Seremban city special education teachers is rejected.

The findings of this study show that there is a significant relationship between teachers' perceptions of using ICT in the classroom. The perceptions of Special Education teachers in this study showed a high level of perceptions but their level of use was moderate. According to Malakia. J \& Cloneria N. J (2018) teachers' positive perceptions have not necessarily increased their use of ICT in the classroom. Although the findings indicate that there is a significant relationship between teachers' perception and use of ICT, the relationship is at a moderate level. This finding is in line with the findings of the Apeanti (2014) study that conducted a study to examine the relationship between teachers' perceptions and the use of ICT found to be moderately significant. Gebremedhin \& Fenta (2015) suggest that there is a significant relationship between teachers' perceptions of using ICT in the classroom. This significant relationship indicates that teachers' perceptions influence the practice of using ICT in the classroom.

\section{RECOMMENDATION RESOLUTIONS}

Some of the proposed research directions for future studies are as follow:

1. Studies examining the problems of Special Education teachers in integrating ICT should be given attention in order to identify the problems of Special Education teachers. This would make it easier for the government to take the initiative in reducing the obstacles faced by Special Education teachers.

2. The criteria to be considered by Special Education teachers in the integration of ICT should also be carried out in the future so that special education teachers can plan and implement the ICT in the classroom. The students with special needs require special attention and needs compared to the mainstream students.

\section{CONCLUSIONS}

The findings show that Special Education teachers have a positive perception towards the use of ICT. However, the level of use of ICT by Special Education teachers is at a moderate level. This explains that Special Education teachers have a positive perception and have a desire to use ICT in teaching and learning. But their frequency of use is low due to several factors. Recent findings conclude that teachers face problems in terms of inaccuracy in ICT, task load, inadequate infrastructure that impede increasing frequency of use of ICT (Tengku Norhayati, 2015). Therefore, the problem needs to be identified and rectified in order to encourage teachers to use ICT in the classroom.

\section{REFERENCES}

Amethyst Consultancy Ltd. (2003). Roamer, Valiant Technology, London, UK. Muat turun pada January 20, 2020, Retrieved from http://www.valiant.technology.com/products/roam er1.htm

Andin, C., Bin, N. Q. B. A. H., \& Pendidikan, A. F. (2010). Penggunaan Teknologi Maklumat Dan Komunikasi (ICT) Dalam Kalangan Guru-Guru Sekolah Kebangsaan. Fakulti Pendidikan Universiti Teknologi Malaysia. Retreived from http://eprints.utm.my/10521/1/Penggunaan_Tekno logi_Maklumat_Dan_Komunikasi. pdf.

Apeanti, W. (2014). Prospective Mathematics Teachers' Perception about ICT Integration in Mathematics Instruction in Ghana. Global Educational Research Journal, 2(10), pp. 174-184.

Ari, I. A. \& Inan, F. A. (2010). Assistive technoogies for Student with Disabilities: A Survey of Access and Use in Turkish Universities. The Turkish Online Journal of Educational Technology, 2010, vol. 9(2), pp. 40-45.

Bingimlas, K. A. (2009). Barriers to the successful integration of ICT in Teaching and Learning Environments: A Review of the Literature. Eurasia Journal of Mathematics, Science \& Technology Education, 5(3).

Chiappe, A., Pinto, R., \& Arias, V. (2016). Open Assessment of Learning: A MetaSynthesis. International Review of Research in Open and Distributed Learning: IRRODL, 17(6), 44-61

Cox, M. J., Cox, K., \& Preston, C. (2000). What Factors Support Or Prevent Teachers From Using ICT In Their Classrooms? Journal of applied social psychology, 28(15), pp. 1429-1464.

Creswell (2012). Educational Research. Boston: Pearson Sdn.Bhd.

Emery, D. W., \& Vandenberg, B. (2010). Special Education Teacher Burnout And ACT. International Journal of Special Education, 25(3), 119-131 
Fessakis, G., Gouli, E., \& Mavroudi, E. (2013). Problem solving by 5-6 years old kindergarten children in a computer programming environment: A case study. Computers \& Education, 63, 87-97.

Florian, L., \& Hegarty, J. (2004). ICT and Special Educational Needs: a tool for inclusion. McGrawHill Education (UK).

Gebremedhin, M. A., \& Fenta, A. A. (2015). Assessing Teachers' Perception on Integrating ICT in Teaching-Learning Process: The Case of Adwa College. Journal of Education and Practice, 6(4), pp. 114-124.

Ghavifekr, S., \& Rosdy, W. (2015). Teaching and Learning with Technology: Effectiveness of ICT Integration in Schools. International Journal of Research in Education and Science, 1(2), pp. 175191.

Gooch, D., Vasalou, A., Benton, L., \& Khaled, R. (2016, May). Using Gamification To Motivate Students With Dyslexia. In Proceedings of the $2016 \mathrm{CHI}$ Conference on human factors in computing systems (pp. 969-980).

Gregor, P., Dickinson, A., Macaffer, A., \& Andreasen, P. (2003). Seeword - A Personal Word Processing Environment For Dyslexic Computer Users. British Journal of Educational Technology 34(3), 341-355.

Hair, Celsi, Mowey, Samuel \& Page. (2016). Essentials of Business Methods Research. New York. Apex Co Vantage, LLC.

Hamzah, M. I., \& Attan, N. (2010). Tahap Kesediaan Guru Sains Dalam Penggunaan Teknologi Maklumat Berasaskan Komputer Dalam Proses Pengajaran Dan Pembelajaran. Jurnal Teknologi, 46(1).

Hassanzadeh, V. (2012). Motivation And Personality Traits Of TESL Postgraduate Students Towards The Use Of Information And Communications Technology (ICT) In Second Language Teaching. English Language Journal, 5(4), p. 74

Hutchison, A. \& Reinking, D. (2011). Teachers' Perceptions of Integrating Information and Communication Technologies Into Literacy Instruction. A National Survey in the United States, Reading Research Quarterly, 46(4), pp. 312-333.

Jamalludian Harun dan Zaidatun Tasir. (2003). Multimedia dalam Pendidikan. Pahang: PTS Publications \& Distributors Sdn. Bhd.

Jamalludin Harun dan Siti Nurulwahida Zainal Abidin (2010). Pembangunan Modul Pembelajaran Berbantukan Video Interaktif Bagi Pembelajaran
Pengaturcaraan Visual Basic Berdasarkan Pendekatan Projek.

Kamis, N., \& Khalid, F. (2017). Kekangan Penggunan Teknologi Maklumat Dan Komunikasi (TMK) Dalam Pengajaran Dan Pembelajaran Guru Prasekolah. Simposium Pendidikan diPeribadikan: Perspektif Risalah An-Nur (SPRiN2017).

Kumaran. (2017). Hubungan Sikap Afektif, Kognitif, dan Tingkah Laku terhadap Penguasaan dan Penggunaan TMK dalam Kalangan Murid Orang Asli. Master Dissertation. Universiti Pendidikan Sultan Idris.

Lay, Y. F., \& Khoo, C. H. (2012). Pengenalan kepada Pendekatan Kuantitatif dalam Penyelidikan Pendidikan (1st ed.). Sabah: Penerbit Universiti Malaysia Sabah.

Malakia Jatileni \& Cloneria N. Jatileni (2018). Teachers' Perception On The Use Of ICT In Teaching And Learning: A Case Of Namibian Primary Education. Theses And Dissertations.

Malaysia, Warta Kerajaan Persekutuan (2013). Peraturan-Peraturan Pendidikan (Pendidikan Khas) 2013.

Nor' Aini Ahmad. (2010). Tahap Kemahiran TMK Dalam Kalangan Guru Bahasa Melayu Sekolah Menengah. Projek Penyelidikan Sarjana Pendidikan. Bangi. Universiti Kebangsaan Malaysia.

Office of the National Education Commission. (2003). Education in Thailand 2003/2004. Bangkok: Office of the National Education Commission.

Patten, M. L., \& Newhart, M. (2017). Understanding research methods: An overview of the essentials. Taylor \& Francis.

Pede, J. (2017). The Effects Of The Online Game Kahoot On Science Vocabulary Acquisition. Theses and Dissertations. FebruarY 7, 2019 , Retrieved from https://rdw.rowan.edu/etd/2405

Plump, C.M. \& LaRosa, J. (2017). Using Kahoot! in the Classroom to Create Engagement and Active Learning: A Game-Based Technology Solution for eLearning Novices. Management Teaching Review 2(2): 151-158.

Prather-Jones, B. (2011). "How School Administrators Influence the Retention of Teachers of Students with Emotional and Behavioral Disorders." The Clearing House: A Journal of Educational Strategies, Issues and Ideas 84 (1): 1-8.

Sánchez-Mena A., Martí-Parreño J. (2017), Teachers' Acceptance of Educational Video Games: a Comprehensive Literature Review, Journal of $e$ - 
Learning and Knowledge Society, v.13, n.2, 47-63. ISSN: 1826-6223, e-ISSN:1971-8829

Shaharuddin, M. S., \& Khairi, A. (2013). MA (2011). Pembangunan Web E-Pembelajaran Menggunakan Elemen Video Dalam Topik 'Work And Energy'Berasaskan Teori Konstruktivisme Sosial.

Sheila Devaraj \& Samsilah Roslan. 2006. Apa itu Disleksia. Kuala Lumpur. PTS Profesional Publishing Sdn. Bhd.

Sim, W. W., \& Norasmah Othman. (2017). Amalan Pengajaran Dan Pembelajaran Abad Ke 21 Dalam Kalangan Guru Sekolah Rendah. In N. Salamuddin, M. T. Harun, M. I. Hamzah, S. H. Wong, S. N. Wan Hassan, \& S. Z. Yassin (Eds.), Prosiding Seminar Penyelidikan Pendidikan Kebangsaan 2017 (p. 477). Selangor: Fakulti Pendidikan, Universiti Kebangsaan Malaysia.

Stevens, C. (2004). Information And Communication Technology, Special Educational Needs And Schools: A Historical Perspective Of UK Government Initiatives. In: Florian, L., Hegarty, J. (eds.) ICT and Special Educational Needs: a Tool for Inclusion, pp. 21-34. Open University Press, Buckingham (2004)

Tengku Norhayati bt tengku Othman. (2015). Teknologi Maklumat dan Komunikasi (TMK) dalam Pengajaran Dan Pembelajaran Guru Cemerlang Pendidikan Islam Di Negeri Selangor. Tesis Sarjana. Universiti Kebangsaan Malaysia.

Van der Molen, M., Van Luit, J. E. H., Van der Molen, M. W., Klugkist, I., \& Jongmans, M. J. (2010). Effectiveness of a computerised working memory training in adolescents with mild to borderline intellectual disabilities. Journal of Intellectual Disability Research, 54(5), 433-447.

Wang, Y. M. (2012). When Technology Meets Beliefs: Preservice Teachers' Perception Of The Teacher's Role In The Classroom With Computers. Journal of Research on Technology in Education, 35(1), pp. 150-161

Williams, P., Jamali, H.R., Nicholas, D. (2006). Using ICT With People With Special Education Needs: What The Literature Tell Us. Aslib Proceedings 58(4), 330-345.

Wilson, A. J., Revkin, S. K., Cohen, D., Cohen, L., \& Dehaene, S. (2006). An Open Trial Assessment Of" The Number Race", An Adaptive Computer Game For Remediation Of Dyscalculia. Behavioral and brain functions, 2(1),2 